\title{
Determination of The Most Suitable Type of Fresh Milk in Istanbul Province
}

\begin{abstract}
Ahmet Semih Uzundumlu
Department of Agricultural Economics, Ataturk University, 25240 Erzurum, Turkey

E-mail: asuzsemi@atauni.edu.tr, ORCID: https://orcid.org/0000-0001-9714-2053

\begin{tabular}{l|l}
\hline A R T I C LE IN F O & A B S T R A C T \\
\hline & The data in this study was provided from 400 households in the Kucukcekmece District of
\end{tabular}

Research Article

Istanbul Province in 2011. Unclustered Proportional Sampling Method was used to determine the sample size of the study. The primary objective of this study was to identify the most suitable type of milk for consumers. In determining the most appropriate type, four criteria were taken into

Received : 27/07/2018

Accepted : 04/11/2018 account. These criteria are hygiene, shelf-life, nutritional content, and price. Based on the data, milk consumption was $30.2 \mathrm{~L}$ per annum per capita in Istanbul Province. The households consist of about 3.7 individuals, and they give importance to hygiene by 26.4 percent, shelf-life by 26.7 percent, nutritional content by 29.6 percent and price by 17.2 percent. 55.3 percent of the households prefer UHT (long of shelf-life Tetra Pac packaged milk which heat-treated range of

Keywords:

AHP $135-150^{\circ} \mathrm{C}$ in a short period of 2-4 seconds) milk, 28.5 percent prefer Pasteurized milk, and 16.2 percent prefer Raw milk. Also, while households gave more importance to price and nutrient content at the raw and pasteurized milk, shelf life and hygiene content at UHT milk. Considering

Milk consumption

Nutrition these criteria, the most suitable type of milk for the consumers was UHT milk. As a result, the

Istanbul national companies marketing pasteurized milk in the research area need advertisement works

Milk preference
\end{abstract}

Türk Tarım - Gıda Bilim ve Teknoloji Dergisi 7(1): 99-104, 2019

\section{İstanbul İlinde En Uygun İçme Süt Tipinin Belirlenmesi}

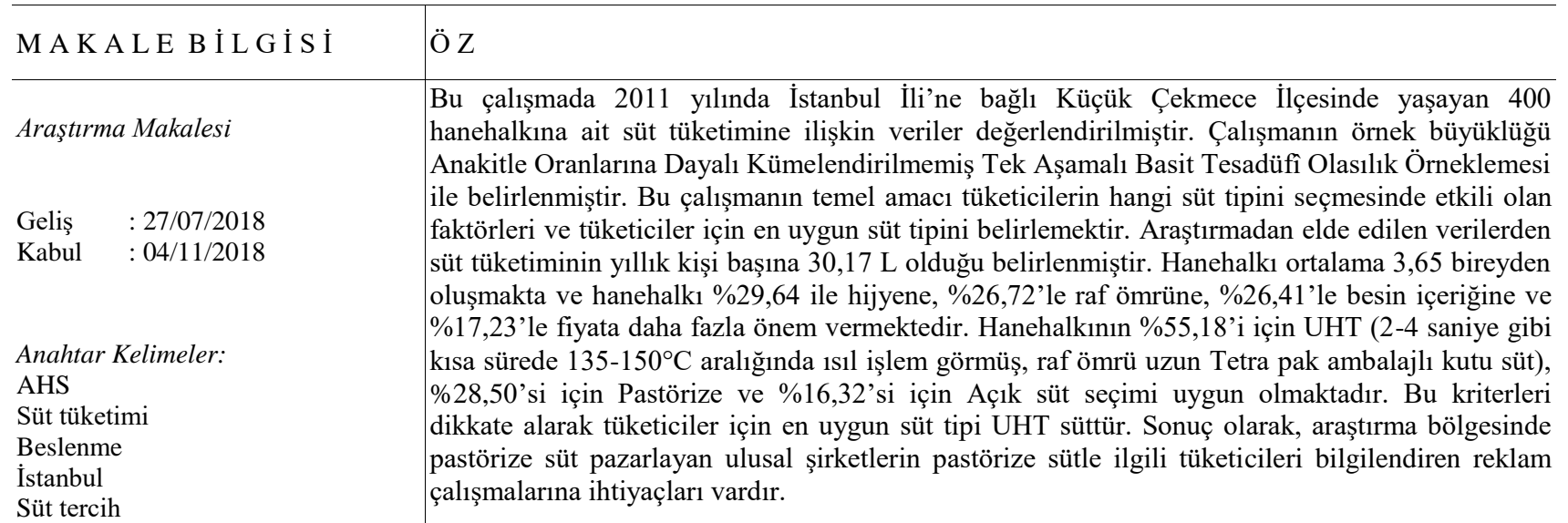

Süt tercih 


\section{Introduction}

Nutrition is a physiological phenomenon which has a significant role in providing the energy required for the continuation of metabolic functions in the body (Orak et al., 2006). Such needs as eating, housing and dressing are one of the most important basic needs of the human beings. It is mandatory to consume adequately the foods of plant and animal origin needed by the human metabolism to maintain a healthy and balanced life (Candemir, 2006). Individuals must eat adequately; have a balanced and healthy diet and gain correct eating habits to maintain their lives in better life quality. One of the significant products of nutrition is milk. Milk is needed for the continuation of human life at each stage from birth to the end of life (Asik, 2006). Also, it is one of the essential foods in the feeding of human beings. According to FAO (2016), milk production and trade in the worldwide are 830.5 and 71.8 million tonnes, respectively in 2017. Also, Turkey is in the ninth place among the countries in the milk production, and it produces approximately $2.4 \%$ of the world milk production (FAO, 2017).

Milk contains many minerals, and especially protein, fat, vitamins and calcium (Chapman and Boor, 2001; Uzundumlu, 2011; Lee, 2016; Wanjala et al., 2017). As percent the mineral content of cow milk is as follows: water: 87.6 , carbohydrate: 4.7 , fat: 3.8 , protein: 3.3 and minerals:0.6 (Demirci and Simsek, 1997; Simsek et al., 2005; Unal and Besler, 2006). However, milk face to face many unfavorable situations from milking to until reaching the consumer. These factors are influencing the nutrition and hygiene status of milk. It is food which can be deteriorated very quickly from production to transportation, storage, processing, and distribution phase (Sarkar, 2015; Wanjala et al., 2017). Due to poor conditions, the shelf-life of milk is shortened by bacteria (Fromm and Boor, 2004). Three processing techniques are performed to prevent the decay of the milk. These techniques are Boiling (15-20 minutes to keep the boiling point), Low-Temperature Long Time (Pasteurization) and High-Temperature Short Time (Sterilization) (Gedam et al., 2007; Uzundumlu, 2011; Lee, 2016).

In scientific studies, it is emphasized that individuals should drink 400-800 ml milk on a daily basis. Fresh milk is consumed as raw and processed (pasteurized and sterilized) in daily nutrition. While most people like hot milk, some people also like it cold. While the consumption of cold milk is generally in processed milk, the hot milk consumption is being at raw milk. Apart from fresh milk, it is also consumed as yogurt, buttermilk, cheese, butter, and milk pudding, etc. (Uzundumlu, 2011).

While the annual liquid milk consumption per capita is determined as $60-170 \mathrm{~kg}$ in developed countries, it is determined as 2-40 kg in developing countries (Hatirli et al., 2004). Milk consumption is also regarded as a development measure, and the consumption of milk and dairy products are generally higher in healthily and adequately nourished communities. Milk is consumed in various ways as milk and dairy products in daily life. The best benefit way from the milk is to use it as drinking.
The reason for this is that particular nutritional values are lost when milk is turned into other products (Demirci and Simsek, 1997; Cetinkaya, 2010).

In this study, the milk consumption behaviors of households, the relation between the socioeconomic and demographic characteristics and their preferences of milk were analyzed econometrically, and the aim was to identify the most suitable type of milk in Kucukcekmece district of Istanbul Province.

It is expected that the information obtained from this study will be valuable to makers and retailers producing and marketing pasteurized, sterilized milk and their products. In the light of this, it is considered that the research results will make significant contributions to the marketing strategies of the national and local companies operating in the sector.

\section{Material and Methods}

\section{Material}

The primary material of the research was obtained by conducting face-to-face interviews with 400 consumers in January-February-March-April 2011 in Kucukcekmece district of Istanbul Province. As the second data source, many local and foreign studies were examined, and the survey forms of this research were prepared with the questions in compliance with the objective of the study.

\section{Methods}

With the information obtained from the municipalities and neighborhood Reeves, the number of surveys to be conducted in each area were determined using the "Unclustered Proportional Sampling Method" taking into account the rate of households (Collins, 1986; Uzundumlu, 2011).

$$
n=\frac{(t)^{2}}{(e)^{2}} \times(p \times q)
$$

$\mathrm{t}$ : $\mathrm{t}$ table value corresponding to 95 percent significance level (1.96)

$\mathrm{p}$ : Probability of occurrence of the event in question

q : Probability of non-occurrence of the event in question

e : Error accepted in the sampling (0.05)

So, when there is no information about the desired situation (p) and undesired situation (q) when $\mathrm{p}$ or $\mathrm{q}$ is 50 percent to 50 percent according to this formula, the maximum sample size is 384 .

$$
\mathrm{n}=\frac{(\mathrm{t})^{2}}{(\mathrm{e})^{2}} \times(\mathrm{p} \times \mathrm{q}) \text { moreover, } \mathrm{n}=\frac{(1.96)^{2}}{(0.05)^{2}} \times(0.5 \times 0.5)=384.2
$$

400 surveys were conducted in Kucukcekmece district taking into account the size of the population. The Analytic Hierarchy Process (AHP) method was used in determining the most suitable type of milk by assessing the survey results. 


\section{Results}

Socio-Economic and Demographic Structure of the Consumers

Ratios of female and male consumers were 59.8 percent, and 40.2 percent, respectively. The consumers involved in the survey were in the age group of 16-73. 46.8 percent of the users consisted of individuals at the age of 30, and below, 29.4 percent of them consisted of the individuals between the ages of 31 and 45 , and 23.8 percent consisted of the age group of 46 years and above. Monthly average income, expense and milk expenditure of the households are TRY 2.462.9, 2,336.6, and 11.5, respectively and milk consumption is $30.2 \mathrm{~L}$ per annum per capita. As the income rises, the milk consumption, and thus the expenditure on milk will increase. AHP

Determination of the most suitable type of milk with

The AHP method is a method based on binary comparisons. The first step is to determine the criteria and their sub-criteria for a particular purpose and to form the hierarchical structure. AHP scientifically helps the decision-maker to make the best choice by prioritizing the alternatives and the criteria affecting those (Scholl et al.,
2005). First, the objective of the study was advised in the AHP method. The purpose of the paper was to identify the most suitable type of milk for the consumers. After the goal of the study is determined, the criteria are outlined in the second stage. In this study, the criteria are price, hygiene, nutritional content and shelf life. After the criteria were determined, the options are listed under the criteria, and a decision tree is created as the last stage. In this study, the consumers have three milk alternatives, which were UHT, pasteurized and raw milk. The decision tree to determine the most suitable type of milk in Kucukcekmece district of Istanbul Province is shown in Figure 1.

In Table 1 , the statistics explaining the options of the AHP method are provided.

UHT milk is suitable for 55.2 percent of the households, Pasteurized milk for 28.5 percent, and Raw milk is suitable for 16.3 percent of the families (Figure 2).

\section{Priorities of the criteria}

In Table 2, the summary statistics of the AHP method of the consumers are provided. Criteria given importance by consumers are nutritional content, shelf life, hygiene, and price, respectively. Percent of these criteria are 29.6, 26.7, 26.4, and 17.2, respectively.

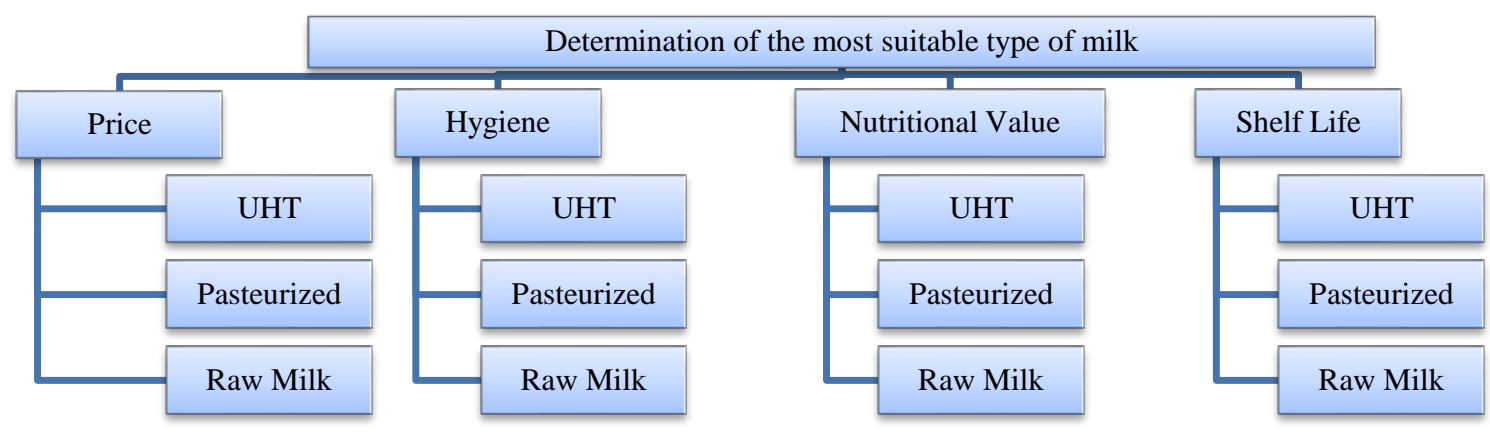

Figure 1 Decision tree in determining the right type of milk

Table 1 Explanatory statistics of the AHP options

\begin{tabular}{l|ccccc}
\hline \multicolumn{1}{c|}{ Types of milk } & Average & Standard error & Minimum & Maximum & Median \\
\hline UHT & 0.5518 & 0.2065 & 0.0510 & 0.8182 & 0.6229 \\
Pasteurized & 0.2850 & 0.1554 & 0.0515 & 0.8189 & 0.2335 \\
Raw milk & 0.1632 & 0.1764 & 0.0515 & 0.8197 & 0.0845 \\
\hline
\end{tabular}

Table 2 Descriptive statistics of the AHP criteria

\begin{tabular}{l|ccccc}
\hline \multicolumn{1}{c|}{ Criteria } & Average & Standard error & Minimum & Maximum & Median \\
\hline Price & 0.1723 & 0.1470 & 0.0269 & 0.7500 & 0.1358 \\
Nutritional Value & 0.2964 & 0.1292 & 0.0481 & 0.7026 & 0.2500 \\
Hygiene & 0.2641 & 0.1038 & 0.0339 & 0.6063 & 0.2500 \\
Shelf life & 0.2672 & 0.1447 & 0.0339 & 0.7519 & 0.2500 \\
\hline
\end{tabular}

Table 3 Comparative averages of the AHP criteria and options

\begin{tabular}{l|cccc}
\hline \multicolumn{1}{c|}{ Criteria } & UHT & Pasteurized & Raw milk & Total \\
\hline Price & 0.49062 & 0.30058 & 0.20879 & 1.00 \\
Nutritional value & 0.53603 & 0.29340 & 0.17058 & 1.00 \\
Hygiene & 0.57315 & 0.29246 & 0.13440 & 1.00 \\
Shelf life & 0.61048 & 0.25440 & 0.13512 & 1.00 \\
Total & 2.21028 & 1.14084 & 0.64889 & 4.00 \\
Rate (percent) & 55.26 & 28.52 & 16.22 & 100.00 \\
\hline
\end{tabular}


Consumption rates according to milk varieties

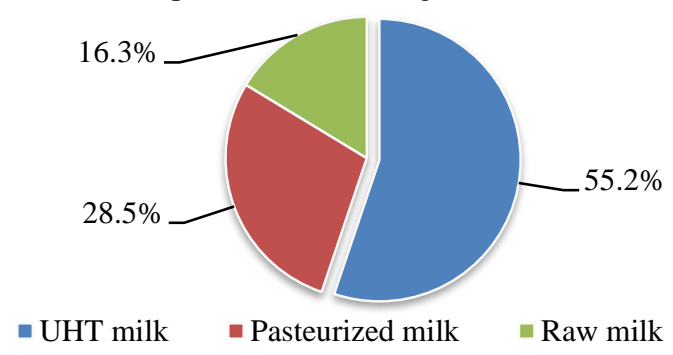

Figure 2 Household milk preferences

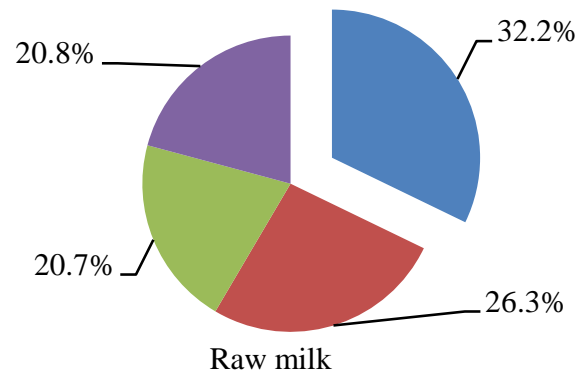

(a)

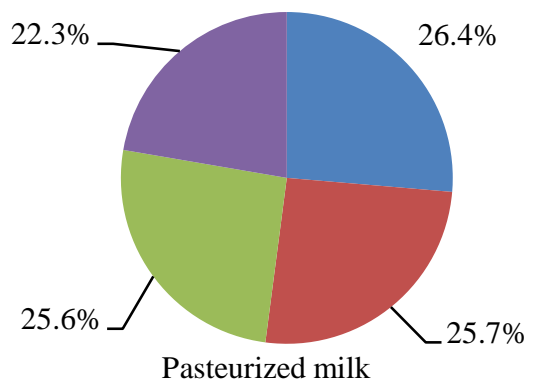

(b)

UHT milk

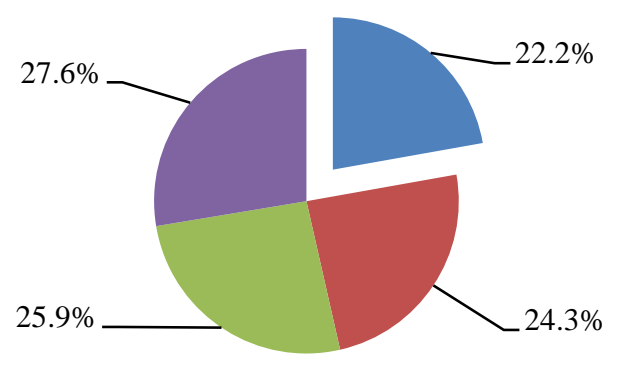

$\square$ Price $\quad$ Nutritional value $\square$ Hygiene $\square$ Shelf life

(c)

Figure 3 The degree of the importance of factors influencing household milk preference

\section{The matrix of criteria and options}

In Table 3, the comparative averages of the AHP criteria and options from the consumers are provided.

According to price criteria in Table 3, 49.1 percent of the users stated that they prefer UHT milk, 30.0 percent pasteurized milk, and 20.9 percent raw milk. If we pay attention, while there is no significant difference in the milk type preference of the consumers, UHT milk took the first place by a long way, and this was followed by pasteurized milk and raw milk. According to the nutritional value criteria, consumers prefer UHT milk at 53.6 percent, pasteurized milk at 29.3 percent, and raw milk at 17.1 percent. According to hygiene criteria, they prefer UHT milk at 57.3 percent, pasteurized milk at 29.3 percent, and raw milk at 13.4 percent. Moreover, according to the shelf-life criteria, they prefer UHT milk at 61.1 percent, pasteurized milk at 25.4 percent, and raw milk at 13.5 percent. Consequently, as a result of the average of these criteria and options in Kucukcekmece district, UHT was more suitable for 55.3 percent, pasteurized milk at 28.5 percent, and raw milk at 16.2 percent. Thus, the most appropriate type of milk for the consumers was UHT milk in Kucukcekmece district. According to Figure 2 household consume UHT, pasteurized and raw milk, respectively. The first one is raw milk. Significant variables for households preferring raw milk were price, food content, shelf life and hygiene that their percentage 32.2, 26.3, 20.8 and 20.7 respectively in this study (Figure $3 \mathrm{a}$ ). The second one is pasteurized milk. The criteria given importance of households in pasteurized milk were price, food content, hygiene, and the shelf life that the percentages of them were 26.4, 25.7, 25.6 and 22.3 respectively (Figure 3b). The last one was UHT milk. The criteria given importance of households in UHT milk were shelf life, hygiene, food content and price that percentages of them were $27.6,25.9,24.3$ and 22.2 respectively in this study (Figure 3c).

\section{Discussion}

The households in the research area consisted of 3.7 individuals, and sex ratios of them were 59.8 percent and 40.2 percent for females and males. Respondents of the study were 16 and 71 age range. The annual fresh milk consumption of the households was $111.7 \mathrm{~L}$, so milk consumption was $30.2 \mathrm{~L}$ per annum, per capita. The consumption of milk in Erzurum Province (Uzundumlu, 2011) found 24.2 L per annum per capita and (Simsek et al., 2005), in the Istanbul Province found $34.0 \mathrm{~L}$ per capita. Like Brazil, Australia, and New Zealand in some Western countries, liquid milk consumption was about 50 to $100 \mathrm{~L}$ per annum per capita (Karenzi, 2015). As the income of households increases, milk consumption and expenditure by the income groups also increase. In developed countries, milk consumption is between 50-100 $\mathrm{L}$ per capita. Although milk was a very significant nutrient in human nutrition, the fresh milk consumption was minimal in Kucukcekmece district just like the rest of Turkey, when compared to the developed countries. Thus, studies should be carried out to increase milk consumption of the consumers in Turkey.

When the factors affecting the milk buying of the consumers were examined into four groups; the price, hygiene, nutritional content, and shelf-life help determine their milk choice. In the study, the orders of the importance of the criteria were nutritional content (29.6\%), shelf-life (26.7\%), hygiene $(26.4 \%)$, and price (17.2\%), respectively. Lu Hsu and Lin (2006) determined that users in China given more importance to the 
nutritional content of these criteria. As mentioned in (Uzundumlu et al., 2018) for shelf-life and brand for individuals living in the province of Erzurum are the most important criteria. Also, Hatirli et al. (2004) said that when consumers decide which type of milk to buy, they see the price as the most crucial factor. Robb et al. (2007) as mentioned in this study, because American consumers were overweight the most important criterion for their milk selection is low-fat content. Bekele et al. (2016) said that Ethiopian consumers generally preferred whole milk because especially the elderly think that whole milk was more beneficial for health even if they were comprehensively informed about benefits of the alternative milk. Andersen and Smed (2012), obtained that Danish consumers preferred high-fat milk, and they pay attention to price more than nutrition content whereas Cash et al. (2005) found that Canadian consumers preferred nutrition content in fatty milk choice but mate group and negative advertising made on the health of the fat milk has been reducing the demand for these milk. Also, Wayua et al. (2009) determined that the taste criteria is more important than the nutrition content in Kenya.

When consumers decide which milk to buy, they consider four criteria for alternative milk. These criteria are the price, hygiene, nutritional content, and shelf-life. The first of alternative milk is raw milk. Variables that the households give importance to raw milk consumption were price by 32.2 percent, the food content with 26.3 percent, the shelf life with 20.8 percent, and the hygiene with 20.7 percent, respectively in this study. Raw milk consumption instance in Turkey is relatively common. So, similar results have been obtained in many studies on raw milk in Turkey. Pazarlioglu et al. (2007) indicate that people think raw milk's nutrient content is higher than other milk. Also, according to Akbay and Tiryaki (2008), consumers thought that raw milk is cheaper, healthier, more hygienic and more accessible to reach than other milk. Yayar (2012) said that consumers prefer farm milk due to misinformation on which raw milk is purer, fresher and more natural. Because some consumers prefer it owing to cheaper and delivered at the doorstep and no additional cost according to processed milk (Akbay and Tiryaki, 2008; Ozel, 2008; Uzundumlu 2011; Yayar 2012). Also, Ozel (2008) determined that the person of households buys raw milk from the familiar and akin persons. The households generally use raw milk in making yogurt. The families prefer raw milk as fresh milk, but concern about the hygiene of the raw milk, the difficulties of finding raw milk from a reliable place, and the fact that processed milk does not require boiling and longer shelf-life of it affect raw milk using negatively. Thus, 16.2 percent of the households generally prefer raw milk as drinking milk. This rate determined as 27.9 percent by Ozel (2008), as 29.3 percent by Uzundumlu (2011), as 16.6 percent by Karakaya and Akbay (2013) and as 23.6 percent by Kaya (2016).

The second one is pasteurized milk. The criteria given more importance of the consumer in pasteurized milk were price by 26.4 percent, the food content with 25.7 percent, and the hygiene with 25.6 percent and the shelf life with 22.3 percent, respectively in this study. According to Watanabe et al. (1999), major positive factors affecting changes in fluid milk consumption included health and taste preferences by consumers. Bus and Worsley (2003) suggests that shoppers widely perceive milk's health effects to fit into five themes related to, weight control, disease prevention, bone health, and causation of allergy and illness. The families consuming pasteurized milk think that the nutritional value of this type of milk is higher than the other milk and prefer this milk when it is cheap. However, the main reason why they do not prefer pasteurized milk is that its shelf-life is short. 28.5 percent of the families generally prefer pasteurized milk as drinking milk. This rate determined as 7.3 percent by Uzundumlu (2011), as 15.2 percent by Karakaya and Akbay (2013) and as 52.9 percent by Kaya (2016).

The last one is UHT milk. The criteria given more importance of the consumer in UHT milk were the shelf life with by 27.6 percent, the hygiene with 25.9 percent, and the food content with 24.3 percent and price with 22.2 percent, respectively in this study. The most crucial factor in the preference of UHT milk of the families is that it is prepared quickly, and it has a long shelf life. Furthermore, UHT milk consumption of the society has increased by degrees as they are far away from their villages and have adapted to the city life. Moreover, a vast majority of the households think that UHT milk is more hygienic and has a higher nutritional value when compared to other milk, and also acknowledge that its price is more reasonable than other milk. A vast majority of the households (55.3 percent) prefer UHT milk for drinking. This rate determined as 63.4 percent by Uzundumlu (2011), as 68.2 percent by Karakaya and Akbay (2013). UHT is the first in the world processed milk market and 94.8 percent, and 5.2 percent of world processed milk constitutes UHT milk, pasteurized milk respectively IPSOS (2014). As in the world, UHT milk consumption in Turkey is more common than the other two milk types.

As a result, UHT milk was determined to be the most suitable type of fresh milk in Kucukcekmece district of Istanbul Province. Thus, the consumers were informed making the necessary explanations while conducting the surveys as the consumers are not adequately informed about pasteurized milk and generally confuse it with UHT milk. For this reason, the companies selling pasteurized milk should promote this type of milk and carry out training and advertisement works in order to give information about it. Also, fresh milk consumption per capita may be increased by providing information to the consumers about the benefits of milk consumption and making children, the next generations, like the milk with such events as the 21 st of May, the World Milk Day.

\section{Conclusion}

Although Turkey has been ranked the ninth biggest milk producer country in the World, annual milk consumption is not at the desired level with $30-50 \mathrm{~kg}$ per capita. For this reason, there is a necessity to studies on increasing milk production and consumption in Turkey. There are three milk type alternatives for Turkish people these are raw, pasteurized and UHT milk. The most important variables for each milk preference are shelf life, nutritional value, hygiene, and price. When these criteria 
are taken into consideration, UHT milk for 55.3 percent, pasteurize milk for 28.5 percent and raw milk for 16.2 percent of consumers are more suitable in the study area. While households gave more importance to price and nutrient content at raw and pasteurized milk, shelf life and hygiene content at UHT milk. If firms deliver milk to consumers by taking these criteria into account and delivering each type of milk in conditions appropriate for consumers will be maximum consumer benefits.

\section{References}

Akbay C, Tiryaki GY. 2008. Unpacked and packed fluid milk consumption patterns and preferences in Turkey. Agricultural Economics, 38(1): 9-20.

Andersen LM, Smed S. 2012. What is it consumers really want, and how can their preferences be influenced? The case of fat in milk. Empirical Economics, 45: 323-347.

Asik H. 2006. Opinions and behaviors related to the beverage consumption of Turks in Germany. Master Thesis, Ins. of Edu. Sci., Gazi University, Ankara, Turkey.

Bekele AD, Beuving J, Ruben R. 2016. Food choices in Ethiopia: Does nutritional information matter? International Journal of Consumer Studies, 40(6): 625-634.

Bus AEM, Worsley A. 2003. Consumers' health perceptions of three types of milk: a survey in Australia. Appetite, 40, 93 100.

Candemir S. 2006. The factors affecting food consumption of families live in rural area of Kahramanmaras and label realities. Master Thesis, Ins.Nat, Appl. Sci. Sutcu Imam University, Kahramanmaras, Turkey.

Cash SB, Wang C, Goddard EW. 2005. Dairy products and consumer demand for healthy foods. Advances in Dairy Technology, 17: 67-80.

Cetinkaya A. 2010. A survey of the consumption habits of milk and milk products among the students in Kafkas University. Ataturk University Journal of Veterinary Science, 5(2): 7384.

Chapman KW, Boor KJ. 2001. Acceptance of 2 percent ultrapasteurized milk by consumers, 6 to 11 years old. Journal of Dairy Science, 84(4): 951-954.

Collins M. 1986. Sampling (Editor: Worcester RM. Downhom J. 1986) Consumer Market Research Handbook. Elsevier Science Publishing Company Inc.

Demirci M, Simsek O. 1997. Dairy processing technology, Harvest Publishing, Istanbul, Turkey.

FAO. 2016. Food and Agriculture Organization's Food Outlook Report, June 2016, http://www.fao.org/3/a-I5703E.pdf. Accessed: March 2017.

FAO. 2017. Food and Agriculture Organization 2010-2016 years statistics. http://www.fao.org/faostat/en/\#data/QL. Accessed: March 2017.

Fromm HI, Boor KJ. 2004. Characterization of pasteurized fluid milk shelf-life attributes. Journal Food Science, 69(8): M207-M214.

Gedam K, Prasad R, Vijay VK, Chanda GC. 2007. The study on UHT processing of milk: A versatile option for rural sector. World Journal Dairy Food Science, 2(2): 49-53.

Hatirli SA, Ozkan B, Aktas AR. 2004. Factors affecting fluid milk purchasing sources in Turkey. Food Quality and Preference, 15(6): 509-515.

IPSOS. 2014. Processed milk market. http://www.ipsos.com/ content/ipsos-first-quarter-2014. Accessed: March 2015.

Karakaya E, Akbay C. 2013. Consumer consumption habits of milk and milk products in Istanbul province. JAF of Uludag University. 27(1): 65-77.
Karenzi E. 2015. Fermentation du kivuguto, lait traditionnel du Rwanda: mise au point d'un starter lactique. PhD Thesis. Université de Liège Gembloux, Liège, Belgique.

Kaya IH. 2016. Consumers' perception and attitudes toward packaged milk in Turkey-a descriptive study. Food and Nutrition Sciences, 7(06): 405-416.

Lee AP. 2016. The role of processing parameters and fat content on sensory perception and consumer acceptance of fluid milk. Graduate Faculty of North Carolina State University Food Sciences, Master Thesis, Raleigh, USA.

Lu Hsu J, Lin YT. 2006. Consumption and attribute perception of fluid milk in Taiwan. Nutrition \& Food Science. 36(3): 177-182.

Orak S, Akgun S, Orhan H. 2006. Investigation of nutritional habits of Suleyman Demirel University students. SDU Journal of Medicine. 13(2): 5-11.

Ozel G. 2008. A research about investigating the factors which are effective on milk choice of consumers. Suleyman Demirel University. SDU Journal Faculty of Economy Administrative Science. 13(3): 227-240.

Pazarlioglu MV, Miran B, Ucdogruk S, Abay C. 2007. Using econometric modeling to predict demand for fluid and farm milk: A case study from Turkey. Food Quality and Preference. 18(2): 416-424.

Robb CA, Reynolds LM, Abdel-Ghany M. 2007. Consumer preference among fluid milk: low-fat vs. high-fat milk consumption in the United States. International Journal of Consumer Studies, 31(1): 90-94.

Sarkar S. 2015. Microbiological considerations: pasteurized milk. International Journal of Dairy Science, 10(5): 206-218.

Scholl A, Manthey L, Helm R, Steiner M. 2005. Solving multiattribute design problems with Analytic Hierarchy Process and Conjoint Analysis: An empirical comparison. European Journal of Operational Research, 164(3): 760-777.

Simsek O, Cetin C, Bilgin B. 2005. A research on the determination of the fresh milk consuming habits and the factors affecting these habits in Istanbul province. Journal of Tekirdag Agriculture Faculty, 2(1): 23-35

Unal RN, Besler T. 2006. Importance of milk in human nutrition. TR Ministry of Health General Directorate of Basic Health Services Department of Food Safety 7, October, Ankara, Turkey.

Uzundumlu AS. 2011. A study on the behaviors of the consumers on the consumption of raw and processed milk in Erzurum province. Ataturk University Graduate School of Natural and Applied Sciences, Ph.D. Thesis, Erzurum, Turkey.

Uzundumlu AS, Birinci A, Kurtoglu S. 2018. Analysis of factors affecting consumers in UHT milk consumption: the case study of Erzurum. Turkish Journal of Agriculture - Food Science and Technology, 6(10): 1485-1492.

Wanjala GW, Mathooko FM, Kutima PM, Mathara JM. 2017. Microbiological quality and safety of raw and pasteurized milk marketed in and around Nairobi Region. African Journal of Food, Agriculture, Nutrition and Development, 17(1): 11518-11532.

Watanabe Y, Suzuki N, Kaiser HM. 1999. Predicting Japanese dairy consumption behavior using qualitative survey data. Agribusiness. 15(1): 71-79.

Wayua F, Shibia M, Mamo M. 2009. Willingness to Pay for Improved Milk Sensory Characteristics and Assurances in Northern Kenya Using Experimental Auctions. International Food and Agribusiness Management Review, 12: 69-88.

Yayar R. 2012. Consumer characteristics influencing milk consumption preference. The Turkey case. Theoretical and Applied Economics, 7(7): 25-42. 